\title{
Performance of some flax genotypes, chemical composition of fibers, seeds and their relation to yield
}

\author{
El-Shimy, G.H.; Mostafa, S.H.A. and Zedan, S.Z.A. \\ Fiber Crops Res. Dept., FCRI, ARC, Giza, Egypt
}

\begin{abstract}
This investigation was conducted at Gemmiza Agric. Res. Station during the two successive winter seasons of 2014/2015 and 2015/2016 to study the differences among nine flax genotypes namelyline 541/D/10, Sakha 2, line 402/11/6, Sakha 3, Giza 9, Ilona, line 22, line 2467/3 and line 435/11. The experiments trails were carried out in Randomized Complete Block Design (RCBD) with four replications. Results revealed that the flax line $541 / \mathrm{D} / 10$ ranked the first and surpass the remain flax genotypes in biological yield/fad., straw yield/fad., fiber yield/fad., fiber $\%$, fiber length, seed yield/fad., seed index, oil \%, oil yield/fad., Iodine value, crude protein $\%$, in seeds and total carbohydrates $\%$ in seeds. But this line occupied the fourth position concerning fiber fineness trait. The flax variety Giza 9 ranked second in all fiber characters, while line 2467/3 was the fewest in biological yield/fad., straw yield/fad., fiber yield/fad. and fiber percentage.

The line 22 ranked second regarding seed yield/fad., oil \% and oil yield/fad. The flax variety Ilona achieved highest estimates for cellulose $\%$, moisture $\%$ in seeds and crude fiber $\%$ in seeds. On the other hand, Ilona gave the lowest estimates in seed yield characters.

Correlation coefficient(r) values were highly significant and positive between fiber yield/fad. and each of biological yield/fad., straw yield/fad., fiber \%, fiber length, fiber fineness, lignin \% and waxes $\%$. While it was significant and positive with each of cellulose $\%$, and pectin $\%$. The $(r)$ values recorded highly significant and positive between seed yield/fad. and each of oil yield/fad., seed index, oil \%, total crude protein $\%$ (in seeds) and total carbohydrates $\%$ (in seeds). While correlation coefficient(r) values were significant and positive with either Iodine value and crude protein $\%$ in seeds.
\end{abstract}

Key Words: flax genotypes, chemical composition of fibers, seeds, yield

\section{Introduction}

Flax (linum usitatissimum L.) consider as a main bast fiber crop in several regions of the world as well as in Egypt which has been known goes back to ancient history and It is grown since several years ago as a dual purpose crop for its fiber from the stems by retting process and oil extracted from the seeds. This crop plays an important role in developing the national economy by its fiber exportation and the local uses for both products i.e., fiber and seeds. Recently, there are gradual increase in world requirements from flax fibers and seeds, where the two products previously mentioned in great importance for several industries, where flax fibers use in manufacturing linen cloth from long fine fiber, tent cloth, twine, best paper. Meanwhile, linseed oil use as edible for human, medical purpose and the remain cake use as dairy cattle feeding. Moreover, that the boiling seed oil use in making paints, varnish and printing ink. In A.R.E., in spite of the increasing which happened in fiber and seed yields per faddan, there was great reduction in flax cultivating area during the last few years which affected negatively on the whole production. Nowadays, flax cultivated area did not enough to cover the gape between the production and consumption especially in linseed oil. Therefore, great efforts are focused on increasing flax productivity by growing high yielding varieties
Many investigators found differences among flax genotypes concerning fiber yield and its related characters such as ), Mourad et al., (2003)), El-Hariri et al., (2004) a,Ottai et al., (2012),Abou El-Nasr et al., (2014) and Bakry et al., (2014), and.On the other hand, El-Hariri et al.,(2012),Bakry etal., (2012) and Hussein (2012) detected significant differences among flax genotypes concerning seed and oil yields.

Respecting chemical compositions of flax fiber and oil, several authors studied this traits among of them El-Hariri et al., (1996), Hanaa (2005), Mostafa et al., (2006 and 2009), Nemat (2006), El-Kady and Abd El-Fatah (2009) and Fikere et al., (2013).

The present investigation was designed to evaluate nine flax genotypes (five promising flax lines in addition to three local varieties i.e. Sakha 2, Sakha 3 and Giza 9 and the imported one Ilona) in relation to yield, technological and chemical attributes for either fiber or seed oil.

\section{Materials and Methods}

This experiment was conducted at Gemmiza Agric. Res. Station Gharbia governorate ARC Egypt during 2014/2015 and 2015/2016 seasons to study the performance of nine flax genotypes concerning straw, fiber seed and oil yields as well as their related characters in addition to quality properties of fiber and seed. The genotypes included the local cultivars Sakha 2, Sakha 3 , Giza 9 and the imported one Ilona 
in addition to promising lines i.e., line $541 / \mathrm{D} / 10$, line 402/11/6, line 22, line 2467/3 and line 435/11 (Table 1) The experiments trails were arranged in Randomized Complete Block Design (RCBD) with four replications. Sowing date was in the second week of November in both seasons; the plot size was $10.5 \mathrm{~m}^{2}$. Plant density of 2500 seeds $/ \mathrm{m}^{2}$ was used and seeds were broadcasted regularly within each plot. Normal cultural practices for flax production as recommended were followed. At maturity, Straw, seed, fiber and oil yields/fad were calculated from the hole plot area basis.

\section{Studied Characters:- \\ I. Fiber yield and its attributes: \\ 1-Biological yield/fad/ (ton) \\ 2-Straw yield/fad.(ton) \\ 3-Fiber yield/fad. (kg)}

4-Fiber percentage. $(\%)$

5-Fiber length. $(\mathrm{cm})$

6 -Fiber fineness $(\mathrm{Nm})$

\author{
II. Seed yield and its attributes: \\ 1-Seed yield/fad. $(\mathrm{kg})$ \\ 2-Seed index (1000 seeds weight in g.) \\ 3 -Seed oil percentage $(\%)$ \\ 4-Oil yield/fad. (kg) \\ 5-Iodine value
}

\title{
III. Fiber chemical composition:-
}

$\begin{array}{lc}\text { 3-Lignin }(\%) & \text { 4- Waxes }(\%) \\ \text { IV. Seed chemical composition:- } & \text { 2-Crude protein \% } \\ \text { 1-Moisture \% } & \text { 4-Crude fiber \% } \\ \text { 3-Total carbohydrates \% } & \\ \text { 5- Ash \% } & \text { 2-Pectin }(\%)\end{array}$

Table 1. Pedigree and plant type (dual purpose, D;fiber type, Fand oil type, O ) of nine flax genotypes.

\begin{tabular}{lll}
\hline Genotype & Pedigree & Type \\
\hline Line $541 / \mathrm{D} / 10$ & S. 2419 X S. 148/6/1 & $\mathrm{D}$ \\
Sakha 2 & I.2348 X Hera & $\mathrm{D}$ \\
Line 402/11/6 & Giza 5 X I. 235 & $\mathrm{D}$ \\
Sakha 3 & Belinka X I. 2096 & $\mathrm{F}$ \\
Giza 9 & S. 420/140/5/10 X Bomby & $\mathrm{F}$ \\
Ilona & A Netherland introduced & $\mathrm{F}$ \\
Line 22 & I. 370 X I. 2561 & $\mathrm{O}$ \\
Line $2467 / 3$ & Selection from I. Neelum & $\mathrm{O}$ \\
Line $435 / 11$ & S. $162 / 12$ x S. 2467/1 & $\mathrm{O}$ \\
\hline
\end{tabular}

\section{Chemical composition of flax fibers:}

Cellulose percentage was estimated according to Jankins method (1930), Pectin percentage was described by Nanji and Norman (1928) and Lignin percentage was described by Ritter et al., (1932)

\section{Chemical composition of flax seed:}

Samples of about $50 \mathrm{~g}$ of air dried seeds of each genotype were randomly chosen from two replications and fine ground for estimating chemical composition. Crude protein, total carbohydrates, oil percentage, moisture content ash \%, crude fiber $\%$ and were determined according to the methods of (AOAC, 2000). All data were statistically analyzed by the analysis of variance method according to Snedcor and Cochran (1982). Differences between means were tested by L.S.D at the level of 0.05 . Bartelett test of homogeneity was adapted indicating no statistical evidence for heterogeneity thus; combined analysis of variance for genotypes overseasons was worked out according to Le Clerg et al., (1966).

Correlation coefficient between some characters followed the same form as out lined by Miller et al., (1959).

\section{Results and Discussion \\ 1-Fibers yield and its related attributes:}

Mean values of fiber yield and its related traits for nine flax genotypes from the combined analysis over the two seasons $(2014 / 2015)$ and (2015/2016) are presented in table (2).

The flax genotypes significantly differed regarding all the six characters i.e., biological yield/fad., straw yield/fad., fiber yield/fad., fiber percentage. fiber length and fiber fineness. Data obtained revealed that the flax line 541/D/10 ranked first and surpass all remain flax genotypes which it recorded 5.85 ton/fad., 4.75 ton/fad., $913.50 \mathrm{~kg} / \mathrm{fad}$., $19.22 \%$ and $92.30 \mathrm{~cm}$. for the respective first five characters, but it occupied the fourth position owing to fiber fineness $(175.30 \mathrm{Nm})$. The flax variety Giza 9 ranked second in all six studied traits with the mean values of $5.57 \mathrm{ton} / \mathrm{fad}$., $4.58 \mathrm{ton} / \mathrm{fad} ., 870.66 \mathrm{~kg} / \mathrm{fad}$., $19.01 \%, 89.40 \mathrm{~cm}$. and $192.60 \mathrm{Nm}$. In the same time, the flax line $2467 / 3$ was the fewest genotype in four characters under study i.e., biological yield/fad. (3.59 ton), straw yield/fad. (2.95 ton), fiber yield/fad. $(523.63 \mathrm{~kg})$ and fiber \% $(17.75 \%)$ in addition to late position in fiber length $(76.50 \mathrm{~cm})$ and fiber fineness $(156.85 \mathrm{Nm})$. The remainder flax genotypes laid intermediate position between highest estimates and the lowest one. The coefficient of variability (C.V.\%) values were greater in fiber yield/fad. (18.57\%), biological yield/fad. (16.84\%), straw yield/fad. $(16.37 \%)$ and fiber fineness $(13.41 \%)$ than in fiber length $(6.62 \%)$ and fiber percentage $(2.59 \%)$. The 
present results are mainly due to the differences in the genetical constitution of genotypes under study. Similar results were also obtained by Mourad et al.
(2003), El-Hriri et al.(2012), Ottai et al.(2012), Abou El-Nasr et al.(2014) and Bakry et al. (2014).

Table 2. Mean values of fiber yield and its related attributes for nine flax genotypes from the combined analysis over seasons (2014/2015 and 2015/2016)

\begin{tabular}{lcccccc}
\hline \multicolumn{1}{c}{ Characters } & $\begin{array}{c}\text { Biological } \\
\text { yield/fad } \\
\text { (ton) }\end{array}$ & $\begin{array}{c}\text { Straw } \\
\text { yield/fad. } \\
\text { (ton) }\end{array}$ & $\begin{array}{c}\text { Fiber } \\
\text { yield/fad } \\
(\mathrm{kg})\end{array}$ & $\begin{array}{c}\text { Fiber } \\
\text { percentage } \\
(\%)\end{array}$ & $\begin{array}{c}\text { Fiber } \\
\text { length } \\
\text { (cm) }\end{array}$ & $\begin{array}{c}\text { Fiber } \\
\text { fineness } \\
(\mathrm{Nm})\end{array}$ \\
\hline Line 541/D/11 & 5.85 & 4.75 & 913.50 & 19.22 & 92.30 & 175.30 \\
Sakha 2 & 5.27 & 4.25 & 779.88 & 18.35 & 83.00 & 163.80 \\
Line 402/11/6 & 3.80 & 3.16 & 568.80 & 18.00 & 76.00 & 153.40 \\
Sakha 3 & 4.25 & 3.51 & 636.01 & 18.12 & 81.10 & 185.60 \\
Giza 9 & 5.57 & 4.58 & 870.66 & 19.01 & 89.40 & 192.60 \\
Ilona & 5.51 & 4.55 & 841.75 & 18.50 & 85.50 & 218.40 \\
Line 22 & 4.65 & 3.83 & 695.15 & 18.15 & 80.00 & 150.06 \\
Line 2467/3 & 3.59 & 2.95 & 523.63 & 17.75 & 76.50 & 156.85 \\
Line 435/11 & 5.09 & 4.16 & 757.54 & 18.21 & 81.20 & 152.93 \\
L.S.D. (5\%) & $\mathbf{0 . 3 9}$ & $\mathbf{0 . 1 9}$ & $\mathbf{4 6 . 5 0}$ & $\mathbf{1 . 2 5}$ & $\mathbf{2 . 6 0}$ & $\mathbf{1 8 . 6 3}$ \\
C.V. \% & $\mathbf{1 6 . 8 4}$ & $\mathbf{1 6 . 3 7}$ & $\mathbf{1 8 . 5 7}$ & $\mathbf{2 . 5 9}$ & $\mathbf{6 . 6 2}$ & $\mathbf{1 3 . 4 1}$ \\
\hline
\end{tabular}

\section{2-Seed yield and its related attributes:-}

Table (3) illustrated the mean values of seed yield and its related characters for nine flax genotypes from the combined analysis over the two seasons 2014/2015 and 2015/2016.

There was significant difference among the nine flax genotypes in all seed traits under study, the flax line 541/D/10 superior over the other eight genotypes in seed yield/fad. (930.60 kg), seed index $(11.60 \mathrm{~g})$, oil percentage $(42.50 \%)$, oil yield/fad. $(395.51 \mathrm{~kg})$ and iodine value (185.60). followed by line 22 which recorded $841.50 \mathrm{~kg}$ for seed yield/fad., $42.00 \%$ for oil percentage and $353.43 \mathrm{~kg}$ for oil yield/faddan. But it ranked the third concerning seed index $(8.54 \mathrm{~g})$ and iodine value (181.92). On the other hand, the flax variety Ilona recorded the minimum estimates in all five seed characters with mean values of 410.00 $\mathrm{kg}, 4.21 \mathrm{~g}, 32.82 \%, 134.58 \mathrm{~kg}$ and 171.00 for the respective five seed characters, respectively. Furthermore, the mean values of seed yield/fad. Ranged from 410.00 to $930.60 \mathrm{~kg}$, seed index from 4.21 to $11.60 \mathrm{~g}$, oil percentage from 32.82 to $42.50 \%$, oil yield/fad. from 134.58 to $395.51 \mathrm{~kg}$ and iodine value from 171.00 to 185.60 . The coefficient of variability estimates exhibited high values in seed index $(35.00 \%)$, oil yield/fad. $(33.70 \%)$ and seed yield/fad. (27.73\%). These results are mainly due to genetical make up of the tested genotypes and are in harmony with those obtained byEl-Hriri et al.(2004 a), Ottai et al.(2011), Bakry et al. (2012) and Hussein (2014)

Table 3. Mean values of seed yield and its related attributes for nine flax genotypes from the combined analysis over seasons (2014/2015 and 2015/2016)

\begin{tabular}{lccccc}
\hline $\begin{array}{c}\text { Characters } \\
\text { Genotypes }\end{array}$ & $\begin{array}{c}\text { Seed } \\
\text { yield/fad.(kg) }\end{array}$ & $\begin{array}{c}\text { Seed Index } \\
(\mathrm{g})\end{array}$ & $\begin{array}{c}\text { Oil percentage } \\
(\%)\end{array}$ & $\begin{array}{c}\text { Oil yield/fad. } \\
(\mathrm{kg})\end{array}$ & Iodine value \\
\hline Line 541/D/11 & 930.60 & 11.60 & 42.50 & 395.51 & 185.60 \\
Sakha 2 & 830.50 & 6.90 & 41.80 & 347.15 & 183.50 \\
Line 402/11/6 & 730.80 & 9.80 & 41.30 & 301.82 & 180.00 \\
Sakha 3 & 460.00 & 4.323 & 37.40 & 172.04 & 174.30 \\
Giza 9 & 490.20 & 4.65 & 37.84 & 185.49 & 175.55 \\
Ilona & 410.00 & 4.21 & 32.82 & 134.58 & 171.00 \\
Line 22 & 841.50 & 8.54 & 42.00 & 353.43 & 181.92 \\
Line 2467/3 & 760.30 & 8.45 & 41.44 & 315.07 & 180.00 \\
Line 435/11 & 625.60 & 8.17 & 39.20 & 245.24 & 178.80 \\
L.S.D. (5\%) & $\mathbf{9 5 . 3 0}$ & $\mathbf{1 . 3 0}$ & $\mathbf{0 . 3 8}$ & $\mathbf{4 0 . 6 0}$ & $\mathbf{3 . 3 0}$ \\
C.V.\% & $\mathbf{2 7 . 7 3}$ & $\mathbf{3 5 . 0 0}$ & $\mathbf{7 . 9 6}$ & $\mathbf{3 3 . 7 0}$ & $\mathbf{2 . 5 9}$ \\
\hline
\end{tabular}

3-Fiber chemical composition:-

The flax genotypes significantly differed in all studied four traits of flax fiber composition from the combined analysis over the two seasons of 2014/2015 and 2015/2016 (Table 4).
The descendent arrangement in mean values regarding cellulose percentage for the nine flax genotypes were Ilona (88.80\%), Giza 9 (81.50\%), Sakha $3(78.60 \%)$, line 541/D/10 (76.20\%), Sakha 2 $(72.50 \%)$, line $2467 / 3(71.90 \%)$, line $402 / 11 / 6$ $(70.04 \%)$, line $435 / 11(69.00 \%)$ and finally line 
$22(66.95 \%)$. The superiority ratios between the highest fiber cellulose \% which obtained by Ilona flax variety $(88.80 \%)$ and each of the other flax genotypes in the same arrangement previously mentioned were $8.96 \%, 12.98 \%, 16.54 \%, 22.48 \%$, $23.50 \%, 26.78 \%, 28.70 \%$ and $32.64 \%$ for the latest flax line 22. It must be mentioned here, that the same regularity which had shown in cellulose percentages mentioned before were in similar trend in fiber fineness character (Table 2), by means that more fiber cellulose $\%$ was more fiber fineness estimate, in addition to more fiber cellulose is more beneficial to make the flax fibers become soft.

Either pectin or lignin \% toke the same arrangement regarding flax genotypes, where line 22 ranked first (3.75 and 2.29\%) followed by line 435/11 (3.62 and 2.21\%), line 402/11/6 (3.45 and $2.15)$, line $2467 / 3$ (3.28 and $2.00 \%)$, Sakha 2 (3.11 and $1.93 \%$ ), line 541/D/10 (2.75 and $1.81 \%)$, Sakha 3 (2.66 and $1.68 \%)$, Giza $9(2.54$ and $1.60 \%)$ and the lowest genotype was Ilona (2.34 and $1.41 \%)$ for pectin and lignin percentages, respectively. It can be observe that pectin \% estimates were always greater than lignin $\%$ in all flax genotypes, both of the two flax fiber components (pectin and lignin) in high percentages were not desired in fibers, in addition to these two materials create when late flax harvest.

In respect to wax percentages, results revealed that this trait was in similar trend with obtained from the arrangement of cellulose \% for the corresponding flax genotypes. The flax variety Ilona recorded maximum fiber wax percentage $(1.88 \%)$ followed by Giza 9 (1.75\%), Sakha 3 (1.69\%), line 541/D/10 (1.62\%), Sakha $2(1.55 \%)$, line $2467 / 3(1.42 \%)$, line $402 / 11 / 6(1.28 \%)$, line $435 / 11(1.22 \%)$ and the lowest was recorded by line $22(1.19 \%)$. The coefficient of variability estimates were $16.50 \%$ for pectin followed by wax (16.36\%), lignin (15.68\%) and cellulose $(9.27 \%)$. These results are in agreement with those obtained byEl-Hriri et al.(1996), Hanaa (2005), Mostafa et al. (2006)and El-Kady and Abd El-Fatah (2009).

Table 4. Mean values of fiber chemical composition for nine flax genotypes from the combined analysis over seasons $(2014 / 2015$ and 2015/2016)

\begin{tabular}{|c|c|c|c|c|c|}
\hline Genotypes & Characters & $\begin{array}{c}\text { Cellulose } \\
(\%)\end{array}$ & $\begin{array}{c}\text { Pectin } \\
(\%)\end{array}$ & $\begin{array}{c}\text { Lignin } \\
(\%)\end{array}$ & $\begin{array}{c}\text { Waxes } \\
(\%)\end{array}$ \\
\hline Line 541/D/11 & & 76.20 & 2.75 & 1.81 & 1.62 \\
\hline Sakha 2 & & 72.50 & 3.11 & 1.93 & 1.55 \\
\hline Line 402/11/6 & & 70.04 & 3.45 & 2.15 & 1.28 \\
\hline Sakha 3 & & 78.60 & 2.66 & 1.68 & 1.69 \\
\hline Giza 9 & & 81.50 & 2.54 & 1.60 & 1.75 \\
\hline Ilona & & 88.80 & 2.34 & 1.41 & 1.88 \\
\hline Line 22 & & 66.95 & 3.75 & 2.29 & 1.19 \\
\hline Line $2467 / 3$ & & 71.90 & 3.28 & 2.00 & 1.42 \\
\hline Line $435 / 11$ & & 69.00 & 3.62 & 2.21 & 1.22 \\
\hline L.S.D. (5\%) & & 6.40 & 0.22 & 0.15 & 0.11 \\
\hline C.V. \% & & 9.27 & 16.50 & 15.68 & 16.36 \\
\hline
\end{tabular}

\section{4- Seed chemical composition:-}

Estimates of seed chemical composition for nine flax genotypes from the combined analysis over the two seasons of 2014/2015 and 2015/2016 are presented in Table (5).

The flax genotypes were significantly differed concerning the five seed chemical composition characters. The great important two traits among of them were crude protein $\%$ and total carbohydrates $\%$, these two characters were in similar trend for flax genotypes, by means that line 541/D/10 achieved highest estimates $(24.36$ and $24.61 \%)$ followed by line 22 (24.11 and 24.38\%), Sakha 2 (23.61 and $24.08 \%)$, S. $2467 / 3$ (23.28 and $23.55 \%)$, line $402 / 11 / 6(23.13$ and $23.39 \%$ ), line 435/11 (22.82 and 23.15\%), Giza 9 (22.54 and 22.92), Sakha 3 (22.25 and $22.43 \%)$ and the lowest one was Ilona (21.98 and $22.15 \%$ ) for crude protein and total carbohydrates $\%$, respectively. The flax genotypes were relatively in similar arrangement in the three seed chemical composition i.e., moisture $\%$, crude fiber $\%$ and ash $\%$. The flax variety Ilona recorded maximum percentages in these respective characters, followed by Sakha 3, Giza 9, line 435/11, line 2467/3, Sakha 2 and either line $521 / \mathrm{D} / 3$ or line 22 . The C.V.\% estimates showed relatively higher values for ash percentage $(12.15 \%)$ and moisture percentage $(7.85 \%)$ than obtained from crude fiber \%, total carbohydrates $\%$ and crude protein $\%$. These results are in agreement with those obtained byNemat (2006), Mostafa et al. (2009) and Fikere et al. (2013).

\section{Conclusion:-}

The promising flax line 541/D/10 superior over the remain flax genotypes in relation to biological yield/fad., straw yield/fad., fiber yield/fad., fiber \%, fiber length, seed yield/fad., seed index, oil $\%$, oil yield/fad., iodine value, crude protein $\%$ and total carbohydrates $\%$. But this flax line was the fourth in fiber fineness. The flax variety Giza 9 occupied the second position in all fiber yield and its related attributes in addition to fiber cellulose $\%$ and waxes $\%$. 
Regarding fiber and seed chemical composition, it can be concluded that the flax variety Ilona characterized by highest fiber quality which contains greatest cellulose $\%$, moderate pectein $\%$ and lowest lignin $\%$ (great lignin $\%$ cause coarse fiber).Therefore, fiber of Ilona variety recorded maximum value of fiber fineness in comparison with line 22 which recorded more lignin $\%$ and coarse fiber. In the same time, seeds of the line 22 contains low moisture $\%$, highest crude protein $\%$ and total carbohydrates $\%$ which produce seeds in high quality for animal feeding and great quality of linseed oil

Table 5. Mean values of seed chemical composition for nine flax genotypes from the combined analysis over seasons (2014/2015 and 2015/2016)

\begin{tabular}{|c|c|c|c|c|c|}
\hline $\begin{array}{ll} & \text { Characters } \\
\text { Genotypes } & \end{array}$ & $\begin{array}{c}\text { Moisture } \\
(\%)\end{array}$ & $\begin{array}{c}\text { Crude } \\
\text { protein } \\
(\%)\end{array}$ & $\begin{array}{c}\text { Total carbohydrates } \\
(\%)\end{array}$ & $\begin{array}{c}\text { Crude fiber } \\
(\%)\end{array}$ & $\begin{array}{l}\text { Ash } \\
(\%)\end{array}$ \\
\hline Line $541 / \mathrm{D} / 11$ & 7.10 & 24.36 & 24.61 & 13.63 & 3.16 \\
\hline Sakha 2 & 7.31 & 23.61 & 24.08 & 13.68 & 3.42 \\
\hline Line $402 / 11 / 6$ & 8.01 & 23.13 & 23.39 & 14.03 & 3.88 \\
\hline Sakha 3 & 8.51 & 22.25 & 22.43 & 15.00 & 4.28 \\
\hline Giza 9 & 8.43 & 22.54 & 22.92 & 14.35 & 4.12 \\
\hline Ilona & 8.75 & 21.98 & 22.15 & 15.21 & 4.51 \\
\hline Line 22 & 7.19 & 24.11 & 24.38 & 13.42 & 3.33 \\
\hline Line $2467 / 3$ & 7.65 & 23.28 & 23.55 & 13.91 & 3.61 \\
\hline Line $435 / 11$ & 8.28 & 22.82 & 23.15 & 14.22 & 4.06 \\
\hline L.S.D. (5\%) & 0.18 & 0.25 & 0.31 & 0.41 & 0.28 \\
\hline C.V. \% & 7.85 & 3.51 & 3.61 & 4.31 & 12.15 \\
\hline
\end{tabular}

\section{Correlation study:-}

1-Correlation coefficient between fiber yield and each of ten related characters.

Data obtained in Table (6) illustrated that the relationship between fiber yield and each of biological yield, straw yield, fiber \%, fiber length, fiber fineness, lignin and waxes were highly significant and positive, while it appeared only significant and positive with cellulose $\%$ and pectin $\%$. The $\mathrm{r}$ values between biological yield and each of straw yield, fiber $\%$, fiber fineness and waxes $\%$ showed highly significant and positive, it was only significant and positive with fiber length, cellulose $\%$, pectin $\%$ and lignin \%.Correlation coefficient between straw yield and each of fiber \%, fiber length, fiber fineness, cellulose $\%$ and pectin $\%$ was highly significant and positive, while it was positive and only significant with lignin $\%$ and waxes $\%$. The association between fiber $\%$ and each of fiber length, fiber fineness, cellulose $\%$ and lignin $\%$ in addition to only significant and positive with waxes $\%$. The $r$ values between fiber length and each of fiber fineness, cellulose $\%$ and pectin $\%$ was positive and highly significant. The relationships between fiber fineness and either cellulose $\%$ or waxes $\%$ exhibited highly significant and positive. Negative and significant correlation coefficient had happened between cellulose $\%$ and each of lignin and waxes $\%$. These results are in agreement with those obtained by Copure et al., (2006) and Ottia et al., (2011)

Table 6. Simple correlation coefficients between fiber yield and some studied characters in flax genotypes from the combined analysis over two seasons 2014/2015 and 2015/2016

\begin{tabular}{|c|c|c|c|c|c|c|c|c|c|c|}
\hline Characters & 1 & 2 & 3 & 4 & 5 & 6 & 7 & 8 & 9 & 10 \\
\hline 1-Fiber yield & ----- & $\begin{array}{c}0.721 \\
* *\end{array}$ & $\begin{array}{c}0.752 \\
* *\end{array}$ & $\begin{array}{c}0.733 \\
* *\end{array}$ & $\begin{array}{c}0.629 \\
* *\end{array}$ & $\begin{array}{c}0.652 \\
* *\end{array}$ & $0.545 *$ & $0.523 *$ & $\begin{array}{c}0.619 \\
* *\end{array}$ & $\begin{array}{c}0.768 \\
* *\end{array}$ \\
\hline $\begin{array}{l}\text { 2- Biological } \\
\text { yield }\end{array}$ & & ----- & $\begin{array}{c}0.660 \\
* *\end{array}$ & $\begin{array}{c}0.648 \\
* *\end{array}$ & $0.525 *$ & $\begin{array}{c}0.607 \\
* *\end{array}$ & $0.500 *$ & $0.524 *$ & $0.535 *$ & $\begin{array}{c}0.631 \\
* *\end{array}$ \\
\hline $\begin{array}{c}3=\begin{array}{c}\text { Straw } \\
\text { yield }\end{array}\end{array}$ & & & ----- & $\begin{array}{c}0.769 \\
* *\end{array}$ & $\begin{array}{l}0.742 \\
* *\end{array}$ & $\begin{array}{c}0.618 \\
* *\end{array}$ & $\begin{array}{c}0.637 \\
* *\end{array}$ & $\begin{array}{l}0.605 \\
* *\end{array}$ & $0.564 *$ & $0.582 *$ \\
\hline 4- Fiber $\%$ & & & & & $\begin{array}{c}0.725 \\
* *\end{array}$ & $\begin{array}{c}0.706 \\
* *\end{array}$ & $\begin{array}{c}0.758 \\
* *\end{array}$ & $\begin{array}{c}0.629 \\
* *\end{array}$ & 0.440 & $0.510 *$ \\
\hline $\begin{array}{l}\text { 5- Fiber } \\
\text { length }\end{array}$ & & & & & ----- & $\begin{array}{c}0.719 \\
* *\end{array}$ & $\begin{array}{c}0.743 \\
* *\end{array}$ & $\begin{array}{l}0.615 \\
* *\end{array}$ & 0.452 & 0413 \\
\hline $\begin{array}{l}\text { 6- Fiber } \\
\text { fineness }\end{array}$ & & & & & & ----- & $\begin{array}{c}0.752 \\
* *\end{array}$ & 0.486 & $\begin{array}{l}-0.604 \\
*\end{array}$ & $\begin{array}{c}0.719 \\
* *\end{array}$ \\
\hline $\begin{array}{c}\text { 7- Cellulose } \\
\%\end{array}$ & & & & & & & --- & 0.497 & $\begin{array}{l}-0.687 \\
* *\end{array}$ & $\begin{array}{c}-0.548 \\
*\end{array}$ \\
\hline 8- Pectin \% & & & & & & & & ----- & 0.403 & -0.302 \\
\hline $\begin{array}{l}9 \text { - Lignin } \% \\
10 \text { - Waxes } \%\end{array}$ & & & & & & & & & ----- & $\begin{array}{c}-0.419 \\
-----\end{array}$ \\
\hline
\end{tabular}


2- Simple correlation coefficients between seed yield per fad. and each of ten related characters area presented in Table (7).

Data obtained exhibited highly significant and positive correlation between seed yield per fad. and each of oil yield per fad., seed index, oil \%, total crude protein $\%$, total carbohydrates $\%$, while only significant and positive with Iodine value and crude fiber $\%$. There was highly significant and positive (r) values between oil yield per fad. and each of seed index, oil $\%$, total crude protein $\%$ and total carbohydrates $\%$. The relation between seed index and each of oil $\%$, total crude protein $\%$, total carbohydrates \% was highly significant and positive, while it was only significant and positive with crude protein $\%$. (r) values between oil $\%$ and total crude protein $\%$ and total carbohydrates $\%$ were significant and positive. These results are in harmony with those obtained by Copure et al., (2006) and Ottia et al., (2011). Plant breeder must take care for straw yield, fiber yield and fiber percentage to increased fiber quantity, in addition to seed index and oil percentage for improving seed yield.

Table 7. Simple correlation coefficients between seed yield and some studied characters in flax genotypes from the combined analysis over two seasons 2014/2015 and 2015/2016

\begin{tabular}{|c|c|c|c|c|c|c|c|c|c|c|}
\hline Characters & 1 & 2 & 3 & 4 & 5 & 6 & 7 & 8 & 9 & 10 \\
\hline 1- Seed yield & ----- & $\begin{array}{l}0.763 \\
* *\end{array}$ & $\begin{array}{l}0.775 \\
* *\end{array}$ & $\begin{array}{l}0.724 \\
* *\end{array}$ & $\begin{array}{c}0.526 \\
*\end{array}$ & 0.451 & $\begin{array}{l}0.715 \\
* *\end{array}$ & $\begin{array}{c}0.616 \\
* *\end{array}$ & $\begin{array}{c}0.523 \\
*\end{array}$ & $\overline{-}-$ \\
\hline 2- Oil yield & & ----- & $\begin{array}{c}0.614 \\
* *\end{array}$ & $\begin{array}{l}0.766 \\
* *\end{array}$ & $\begin{array}{c}- \\
0.418\end{array}$ & 0.356 & $\begin{array}{c}0.624 \\
* *\end{array}$ & $\begin{array}{c}0.593 \\
* *\end{array}$ & 0417 & -0415 \\
\hline 3- Seed Index & & & ----- & $\begin{array}{l}0.618 \\
* *\end{array}$ & 0.461 & 0.319 & $\begin{array}{l}0.708 \\
* *\end{array}$ & $\begin{array}{c}0.617 \\
* *\end{array}$ & $\begin{array}{c}0.516 \\
*\end{array}$ & 0.463 \\
\hline 4- Oil \% & & & & ----- & 0.475 & 0.412 & $\begin{array}{c}0.673 \\
* *\end{array}$ & $0.514 *$ & 0.430 & $\begin{array}{c}-0510 \\
*\end{array}$ \\
\hline $\begin{array}{l}\text { 5- Iodine value } \\
6 \text { - Moisture } \%\end{array}$ & & & & & ---- & $\begin{array}{c}0.313 \\
----\end{array}$ & $\begin{array}{c}0.417 \\
-0.618 \\
* *\end{array}$ & $\begin{array}{c}0.421 \\
-0.625 \\
* *\end{array}$ & $\begin{array}{c}0.314 \\
0.516 \\
*\end{array}$ & $\begin{array}{l}0.403 \\
0.411\end{array}$ \\
\hline $\begin{array}{l}7 \text { - total crude } \\
\text { protein } \%\end{array}$ & & & & & & & ----- & $0.543 *$ & $\begin{array}{c}0.531 \\
*\end{array}$ & 0.436 \\
\hline $\begin{array}{l}8-\text { Total } \\
\text { carbohydrates \% }\end{array}$ & & & & & & & & ----- & $\overline{-}$ & $\begin{array}{c}- \\
0.513 \\
*\end{array}$ \\
\hline 9- Crude fiber $\%$ & & & & & & & & & --- & 0.418 \\
\hline 10- Ash \% & & & & & & & & & & ----- \\
\hline
\end{tabular}

\section{References}

Abou El-Nasr, T.H.S., M.S. Hassanein, M.E.S. Ottai and M.A. Al-Kordy (2014).Diversity Among Five Romanian Linseed Varieties Under Egyptian Conditions. Middle East J. Appl. Sci., 4(1): 114121.

AOAC (2000). Official Methods of Analysis, of the Association of Official Analytical Agricultural Chemists, $17^{\text {th }}$ ed. Published by A.O.A.C.

Bakry, A.B., O.M.; Ibrahim, T.A.Elewa and M. F.,El-Karamany. (2014). Performance Assessment of Some Flax (Linum usitatissimum L.) Varieties Using Cluster Analysis under Sandy Soil Conditions. Agric. Scie.Vol.5 No.8, Article ID:48011,10 pages

Bakry, A.B., Nofal, O.A. and Zeidan, M.S. (2012). Agronomic Characteristics of Three Flax Varieties as Affected By Some Sources of Potassium Fertilization Under Newly Reclaimed Sandy Soil Conditions. Australian Journal of Basic and Applied Sciences, 6: 77-81.
Copur, O., M.A. Gur, M. Karakus and U. Demirel (2006). Determination of correlation and path analysis among yield components and seed yield in oil flax varieties (Linum usitatissimum L.). J. Biol. Sci., 6: 738-743.

El-Hariri, D.M., Bakry, A.B., Elewa, T.A. and Ibrahim, O.M. (2012). Evaluation of Some Flax (Linum usitatissimum L.) Varieties under the Conditions of Newly Reclaimed Sandy Soils. International Journal of Academic Research, 4: 98- 102.

El-Hariri, D.M., M.S. Hassanein and A.H. El-Sweify (2004a). Evaluation of some flax genotypes straw yield, yield components and technological characters. J. of Natural Fibers, 1(2): 1-12.

El-Hariri, D.M.; A.H.H. El-Sweify and S.H. Mostafa (1996). Response of flax yield and quality to cultivars phytohormone levels and pulling dates. $4 \mathrm{TH}$ workshop of the FAO on flax. Rouan, France, Sept. 25/28 P.: 117-128.

El-Kady, E.A.F. and Abd El-Fatah, A.A.E. (2009). Comparison of Yield, Its Components, Physical 
Properties and Chemical Composition of Twelve Flax Varieties. J. of Agric.1 Res.:35, 69-85.

Fikere, M., F. Mekbib and A. Wakjira, (2013). Seed oil diversity of Ethiopian linseed (Linum usitatissimum L.) landraces accessions and some exotic cultivars. African Journal of Biochemistry Research, 7: 76-85.

Hanaa Abd El-Rhaman E.I. (2005). Biochemical studies on Linseed oil $\mathrm{PhD}$.Thesis, Fac. Of Agric. Cairo Univ.

Hussein, M.M.M. (2012). Evaluation of productivity and quality for some local and introduced flax (Linum usitatissimum L.) varieties under different pulling dates in sandy soils. Minufiya J. Agric. Res. Vol. 37 (2012) NO. 5: 1171-1190

Jenkins, S.H. (1930). Determination of cellulose in straw. Biochem. J. 24, 1428

Le Clerg, E.; W.E., Leonard and A.G., Clark (1966). Field plot technique. Burgross Publishing Co. Minneapolis. Minnesota.

Miller,P.A.; J.C., Williams and H.F.,Robirson (1959). Variety - environment interaction and their implication on testing methods. Agron.J., 51: 132-135.

Mostafa, S.H., Amal H. Selim and M.N. Abd-ElAziz (2006). Morphological, biochemical and agronomical identification of some flax (Linum usitatissimum L.) genotypes. First Field Crops Conference 22-24 August P: 223-231.

Mostafa, S.H.A., Aziza M.Hassanein and Nemat A.Naguib (2009). Evaluation of quantitative and qualitative characteristics in some flax genotypes. Egypt J. Plant Breed. 13: 155-172.
Mourad, N.K.M.; H.M.H. Abo-Kaied; E.A. El-Kady; M.E.A. Kineber; Eman A.A. El-Kady; E.L. Mahmoud; G.H. El-Shimy; A.H.El-Sweify; S.H.A. Mostafa; T.A. Abou-Zaid; I.E. El-Deeb and S.Z. Zedan (2009). Performance and stability of the new flax varieties "Giza 9 and Giza 10". Egypt J. appl. Sci. 24 (11): 136-147.

Nanji, D.R. and Norman, A.G. (1928). Pectin estimation of the individual pectic substances in nuture. Biochem. J. 22, 599.

Nemat A. Naguib (2006).Evaluation ofseed quality of different flax seed genotypes (Linum usitatissimum L.). Proc.The First Field Crops Conference (Giza) Egypt 22-24 August.

Ottai, M.E.S., M.A.A. Al-Kordy and S.A. Afiah, (2011). Evaluation, correlation and path coefficient analysis among seed yield and its attributes of oil flax (Linum usitatissimum L.) genotypes. Australian J. of Basic and Applied Sciences, 5: 252-258

Ottai M.E.S., Al-Kordy M.A.A., Hussein R.M. and Hassanein M.S. (2012)Genetic Diversity Among Romanian Fiber Flax Varieties Under Egyptian Conditions. Aust. J. of Basic and Applied Sciences, 6(3): 162-168

Ritter, G., Seborg, J.R. and Mitchell, R.I. (1932). Factors affecting determination of lignin by 72 percent sulphoric acid method. Ind. Eng. Chem., Annal,. 4:202.

Snedecor, G.W. and Cochran, W.G. (1982) Statistical Method. 7th Edition, Iawa State University Press, Ames, 325-330. 


\title{
أداء بعض التراكيب الوراثية من الكتان من حيث التركيب الكميائى للألياف والبذوف وعلاقتهم بالمحصول
}

\author{
جمال الدين حسن الثيمى ، صابر حسين أحمد مصطفى ، سعيد ذكى عبد الحميد زيدان

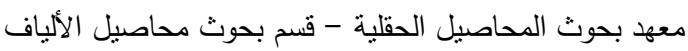

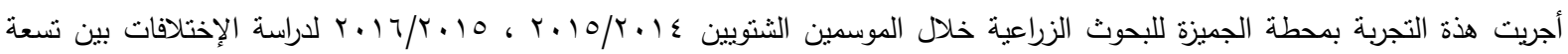

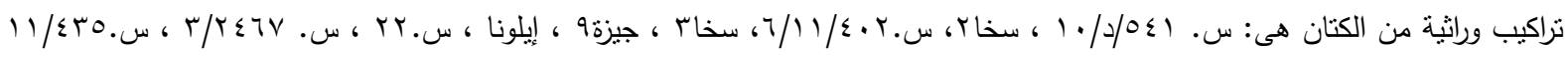

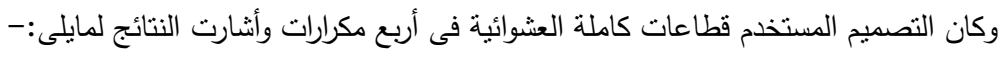

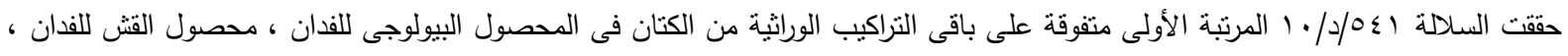

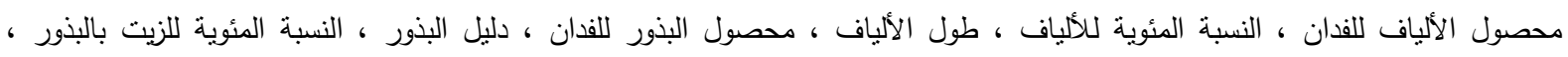

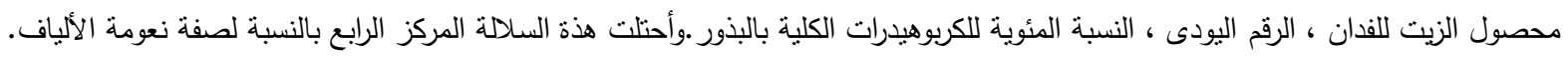

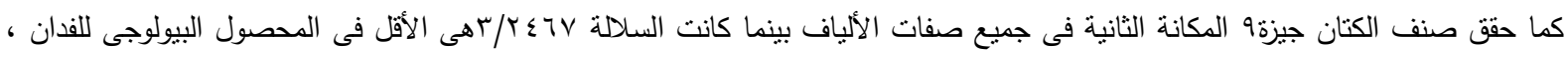
محصول القش للفدان ، محصول الألياف للفدان والنسبة المئوية للألياف.

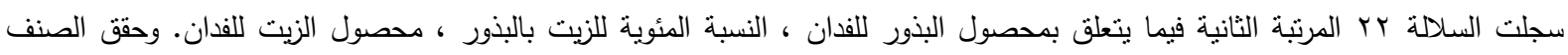

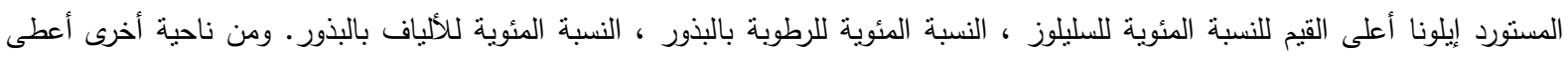

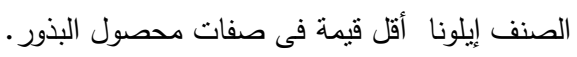

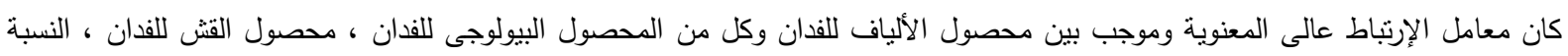

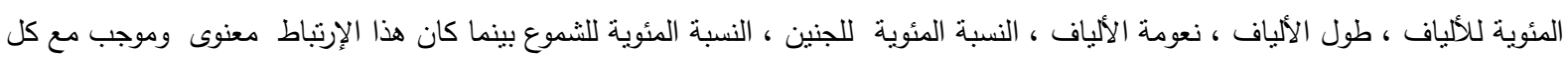
من النسبة المئوية للسليلوز ، النسبة المئوية للبكتين.

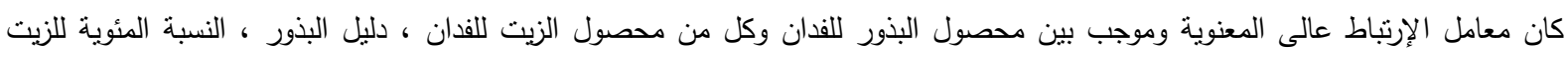

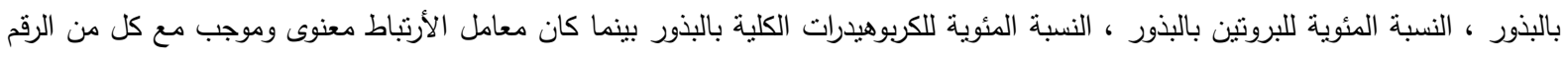

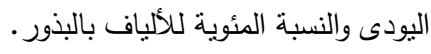

